Republican Jesus 



\title{
Republican Jesus
}

\author{
How the Right \\ Has Rewritten the Gospels
}

TONY KEDDIE

따

UNIVERSITY OF CALIFORNIA PRESS 
University of California Press

Oakland, California

(C) 2020 by Tony Keddie

Cataloging-in-Publication Data is on file at the Library of Congress.

ISBN 978-0-520-35623-8 (cloth : alk. paper)

ISBN $978-0-520-97602-3$ (ebook)

Manufactured in the United States of America

$\begin{array}{llllllllll}28 & 27 & 26 & 25 & 24 & 23 & 22 & 2 \mathrm{I} & 20 \\ \text { I0 } & 9 & 8 & 7 & 6 & 5 & 4 & 3 & 2 & \text { I }\end{array}$ 
For my dad 
